\title{
Preoperative Evaluation of Internet Usage Characteristics of Patients in an Anesthesiology Clinic: A Survey of 1000 Patients
}

\author{
Banu Eler Çevik, Yücel Yüce, Kutlu Hakan Erkal
}

Department of Anaesthesiology and Reanimation, Kartal Dr. Lütfi Kırdar Training and Research Hospital, İstanbul, Turkey

Submitted: 10.01.2018 Accepted: 25.01.2018

Correspondence: Banu Eler Çevik, Kartal Dr. Lütfi Kırdar Eğitim ve Araştırma Hastanesi, Anesteziyoloji ve Reanimasyon Kliniği, İstanbul, Turkey

E-mail: banueler@yahoo.com

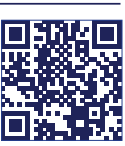

Keywords: Anesthesia; internet; patient; preoperative

\begin{abstract}
Objective: This study was conducted to provide data about current preferences about internet use to obtain information about anesthesiology in patients undergoing elective surgical operations at a tertiary hospital.
\end{abstract}

Methods: After receiving institutional ethics committee approval, 1000 consecutive patients presenting at the Anesthesiology Clinic were interviewed using a questionnaire as a part of their preoperative clinic visit before an elective surgical procedure. Informed consent was obtained from all of the participants. Statistical analysis of all of the completed questionnaires was performed using NCSS statistical software (NCSS, LLC, Kaysville, UT, USA). A chi-square test was used to evaluate categorical variables and a t-test was applied to assess continuous variables. Statistical significance was accepted at $p<0.05$.

Results: Of 1000 patients, 659 (65.9\%) reported routine use of the internet; 559 (55.9\%) of these users were able to get the necessary healthcare information from the internet. In all, 636 patients $(63.6 \%)$ searched for "anesthesia," 387 (38.7\%) searched for "general anesthesia," 245 (24.5\%) searched for "spinal anesthesia," I 30 (I3\%) for "epidural anesthesia," 589 (58.9\%) for "anesthesia-related complications," 498 (49.8\%) for "anesthesia-related deaths" and 33 I (33.I\%) for "other medical subjects." The remaining 364 patients (36.4\%) responded that they did not search for any subject related to anesthesia on the internet.

Conclusion: Actual, evidence-based knowledge should be made available on the internet sites of health institutions to provide correct, understandable, and reliable information for the patients and their relatives. Preoperative information about the anesthesiology procedures and possible complications helps them to cope with anxiety due to uncertainty and lack of information.

\section{INTRODUCTION}

As in all other fields of science, the internet is increasingly becoming a source of knowledge in medicine. The growing number of patients using the internet is also a result of the increase in the number of people using the internet overall. Several studies have reached this conclusion. Surgical patients are often anxious before the operation due to a lack of knowledge about the procedures in the operating room. Therefore, they may try to find information online about the surgery and anesthesia and the potential risks. But several studies have reported that the number of patients who obtained information about their surgical procedure and anesthesia was deficient. ${ }^{[1-3]}$ Patients still rely on public opinion about surgery and in particular, anesthesia. Their knowledge about these procedures is typically not based on systematic investigations using different sources. ${ }^{[4-6]}$ The aim of this study was to evaluate the characteristics of internet usage regarding anesthesia by patients in the preoperative period. 


\section{MATERIAL AND METHODS}

A survey study was performed in the anesthesiology clinic of a tertiary education and research hospital between February 2017 and April 2017 after receiving approval from the Kartal Dr. Lutfi Kirdar Education and Research Hospital ethics committee. In all, 1000 consecutive patients aged between 18 and 80 years were recruited into this study. They were interviewed using a questionnaire as a part of their preoperative anesthesiology clinic visit before an elective surgical procedure. Patients with mental retardation, severe psychiatric disorders, and those who declined to take part in the study were excluded. Written informed consent was obtained from all participants.

All of the questionnaires were completed and returned before the surgical procedure. The survey consisted of 3 parts containing questions about the demographic characteristics of the participants, their previous knowledge about anesthesia and the internet use, and their recent internet usage (Table I-3).

Patients were grouped according to age, gender, educational, and economic status. The patients were classified into 3 income subgroups: low, moderate, and high income.
Patient characteristics are presented as number ( $\mathrm{n}$ ) and percentage (\%). Statistical analysis was performed on all completed questionnaire data using NCSS software (NCSS, LLC, Kaysville, UT). In addition to descriptive statistics (frequency, ratio), a chi-square test was used to examine qualitative data. A chi-test was used to evaluate categorical variables and a t-test to assess continuous variables. Statistical significance was accepted at $p<0.05$.

\section{RESULTS}

Of 1000 consecutive patients referred to the clinic preoperatively regarding anesthesia, all of them agreed to participate in our study program and none were excluded. In all, $69 \%$ of the 1000 patients were classified as American Society of Anesthesiology (ASA) physical status I, 20\% were classified as ASA II, and II\% of them were classified as ASA III. A total of 564 of the participants were male (56.4\%) and 436 (43.6\%) were female (male/female ratio: I.3).

The evaluation of internet use according to age revealed that $306(30.6 \%)$ of the patients were $<30$ years of age, $517(51.7 \%)$ were between 30 and 60 years, and the remaining 177 patients were over 60 years of age (I7.7\%).

Table I. Demographic characteristics of the patients and relationships between internet usage and the demographic data

\begin{tabular}{|c|c|c|c|c|c|c|c|}
\hline \multirow[t]{2}{*}{ Demographic characteristics } & \multicolumn{2}{|c|}{$\begin{array}{l}\text { Total sample } \\
(n=1000)\end{array}$} & \multicolumn{2}{|c|}{$\begin{array}{l}\text { Internet usage }(+) \\
\quad(n=659)\end{array}$} & \multicolumn{2}{|c|}{$\begin{array}{l}\text { Internet usage (-) } \\
\qquad(n=341)\end{array}$} & \multirow[t]{2}{*}{$\mathbf{p}^{*}$} \\
\hline & $\mathbf{n}$ & $\%$ & $\mathbf{n}$ & $\%$ & $\mathbf{n}$ & $\%$ & \\
\hline Age (years) & & & & & & & $<0.001$ \\
\hline$<30$ & 306 & 30.6 & 285 & 43.2 & 21 & 6.2 & \\
\hline $30-60$ & 517 & 51.7 & 340 & 51.6 & 177 & 51.9 & \\
\hline$>60$ & 177 & 17.7 & 34 & 5.2 & 143 & 41.9 & \\
\hline Gender & & & & & & & $<0.05$ \\
\hline Male & 564 & 56.4 & 409 & 62.1 & 155 & 45.5 & \\
\hline Female & 436 & 43.6 & 250 & 37.9 & 186 & 54.5 & \\
\hline Employment status & & & & & & & $<0.001$ \\
\hline Employed & 703 & 70.3 & 543 & 82.4 & 40 & 11.7 & \\
\hline Unemployed & 297 & 29.7 & 116 & 17.6 & 301 & 88.3 & \\
\hline Educational status & & & & & & & $<0.001$ \\
\hline Primary school & 124 & 12.4 & 51 & 7.7 & 73 & 21.4 & \\
\hline Middle school & 359 & 35.9 & 220 & 33.4 & 139 & 40.8 & \\
\hline High school & 334 & 33.4 & 212 & 32.2 & 122 & 35.8 & \\
\hline University & 183 & 18.3 & 176 & 26.7 & 7 & 2 & \\
\hline Economic status (monthly income) & & & & & & & $<0.05$ \\
\hline$<1000 \mathrm{TL}$ & 231 & 23.1 & 54 & 8.2 & 177 & 51.9 & \\
\hline $1000-4000 \mathrm{TL}$ & 661 & 66.1 & 528 & 80.1 & 133 & 39 & \\
\hline$>4000 \mathrm{TL}$ & 108 & 10.8 & 77 & 11.7 & 31 & 9.1 & \\
\hline
\end{tabular}

aPearson chi-square test; ${ }^{6}$ Fisher-Freeman-Halton test; ${ }^{*} \mathrm{p}<0.05$. 
Table 2. Multiaspect evaluation of patient internet information

\begin{tabular}{|c|c|c|}
\hline & $\mathbf{n}$ & $\%$ \\
\hline \multicolumn{3}{|c|}{ Where did you learn about anesthesia? } \\
\hline Previous operation & 564 & 56.4 \\
\hline Relatives & 242 & 24.2 \\
\hline TV & 35 & 35 \\
\hline Internet & 159 & 15.9 \\
\hline \multicolumn{3}{|l|}{ Do you use the internet? } \\
\hline No & 341 & 34.1 \\
\hline Yes & 659 & 65.9 \\
\hline \multicolumn{3}{|c|}{ Do you have an e-mail address? } \\
\hline No & 413 & 41.3 \\
\hline Yes & 587 & 58.7 \\
\hline \multicolumn{3}{|c|}{ Did you check the internet related to } \\
\hline \multicolumn{3}{|c|}{ your problem prior to the surgery? } \\
\hline No & 441 & 44.1 \\
\hline Yes & 559 & 55.9 \\
\hline \multicolumn{3}{|c|}{ Did you find the healthcare information } \\
\hline \multicolumn{3}{|l|}{ from the internet useful? } \\
\hline No & 543 & 54.3 \\
\hline Yes & 437 & 43.7 \\
\hline \multicolumn{3}{|c|}{ Do you rely on healthcare information } \\
\hline \multicolumn{3}{|l|}{ from the internet? } \\
\hline No & 354 & 35.4 \\
\hline Yes & 646 & 64.6 \\
\hline
\end{tabular}

With respect to educational status, internet use among patients with a primary school, middle school, high school, and university level education was 124 (12.4\%), 359 (35.9\%), 334 (36.3\%), and 183 (18.3\%) respectively.

Assessment of internet use according to patient income indicated $23.1 \%(n=231)$ usage in the low income group, $66.1 \%(n=661)$ in the intermediate income group, and $10.8 \%(n=108)$ in the high income group.

Overall analysis of our data between the subgroups demonstrated that there was a statistically significant relationship between internet use and age $(p<0.001)$, gender $(p<0.05)$, educational status $(p<0.00 \mathrm{I})$, and economic situation $(p<0.05)$ (Table I).

Of all of the the respondents in the study, 659 (65.9\%) reported routine use of the internet, and of these users, $559(55.9 \%)$ were able to get the necessary healthcare information from the internet. Among the internet users, 587 patients $(58.7 \%)$ had an email account. The general characteristics and responses of the study groupo concerning internet use and searching for medical information are summarized in Table 2.
Table 3. Topics related to anesthesia researched on the internet by the patients

\begin{tabular}{lcc}
\hline & $\mathbf{n}$ & $\%$ \\
\hline Anesthesia & 636 & 63.6 \\
General anesthesia & 387 & 38.7 \\
Spinal anesthesia & 245 & 24.5 \\
Epidural anesthesia & 130 & 13.0 \\
Complications of anesthesia & 589 & 58.9 \\
Anesthesia deaths & 498 & 49.8 \\
Others & 331 & 33.1 \\
\hline
\end{tabular}

Table 4. Knowledge of the patients about anesthesia

\begin{tabular}{|c|c|c|}
\hline & $\mathbf{n}$ & $\%$ \\
\hline \multicolumn{3}{|l|}{ Previous operation } \\
\hline$(+)$ & 564 & 56.4 \\
\hline$(-)$ & 436 & 43.6 \\
\hline \multicolumn{3}{|c|}{ Do you know what anesthesia is? } \\
\hline Yes & 869 & 86.9 \\
\hline No & $|3|$ & 13.1 \\
\hline \multicolumn{3}{|l|}{ Fear of anesthesia } \\
\hline$(+)$ & 675 & 67.5 \\
\hline$(-)$ & 325 & 32.5 \\
\hline \multicolumn{3}{|c|}{ Who administers anesthesia? } \\
\hline Surgeon & 378 & 37.8 \\
\hline Anesthesist & 432 & 43.2 \\
\hline Nurse & 117 & 11.7 \\
\hline Technician & 73 & 7.3 \\
\hline \multicolumn{3}{|c|}{ Where did you learn about anesthesia? } \\
\hline Previous operation & 564 & 56.4 \\
\hline Relatives & 242 & 24.2 \\
\hline TV & 35 & 3.5 \\
\hline Internet & 159 & 15.9 \\
\hline \multicolumn{3}{|c|}{ Do you want to see your anethesist } \\
\hline \multicolumn{3}{|l|}{ before the operation? } \\
\hline Yes & 651 & 65.1 \\
\hline No & 349 & 34.9 \\
\hline
\end{tabular}

Of the participants, $15.9 \%$ reported that they had learned about anesthesia from internet sources and $64.6 \%$ of them described the information gathered from internet sources as adequate, but $35.4 \%$ considered it inadequate.

Our data demonstrated that 636 patients $(63.6 \%)$ used the search term "anesthesia," 387 (38.7\%) searched for "general anesthesia," 245 (24.5\%) searched for "spinal anesthe- 
sia," I 30 (I3\%) for "epidural anesthesia," 589 (58.9\%) for "anesthesia-related complications," 498 (49.8\%) for "anesthesia-related deaths," and 33 I (33.I\%) for "other medical subjects." The remaining 364 patients (36.4\%) responded that they did not search for any subject related to anesthesia on the internet (Table 3).

Most of the patients in our study were familiar with the term "anesthesia" (86.9\%), and for 56.4\% that knowledge was due to previous operations. Nearly half replied correctly that the anesthetist administers the anesthesia (43.2\%). In all, 67.5\% reported a fear of anesthesia and $65.1 \%$ of them wanted to see their anesthetist before the operation (Table 4).

\section{DISCUSSION}

Developments in technology have revolutionized communication. The internet is a continuously growing worldwide communication network with information resources related to most areas of everyday life. ${ }^{[7]}$ As in other fields of science, the internet has become a favorite source of information about health issues due to the ease of finding answers. ${ }^{[8]}$

Patients frequently search for information online in many different medical disciplines, including anesthesia. There are several reports with varied results about the availability and usage rates of particular groups of patients. The international website, Internet World Stats, has indicated that the worldwide number of users is 2,405,5 I8,376 and 200 million are in the USA. ${ }^{9]}$ Although internet access is rapidly increasing in our country, easy access is still not available in all parts of the country. According to Turkish Statistical Institute data, the rate of internet access in Turkey is $60.2 \% .^{[10]}$ In our study, $37.8 \%$ of the patients within the age group of 18 to 80 years used the internet regularly (nearly every day or at least once every week).

Similar to other studies assessing the relationship between demographic variables and internet use, ${ }^{[1]}$ the evaluation of our data also showed a positive correlation between higher educational and economic status and greater internet use. Furthermore, there was a negative correlation between age and the frequency of internet use and a positive relationship in favor of male gender. It was demonstrated that younger generations used the internet more often than older adults. ${ }^{[12]}$

Regarding the use of the internet to get information about current health-related problems, it has been reported that the patients may look for either specific or general topics. Schwartz et al. ${ }^{[13]}$ found that $79 \%$ of patients searched for particular issues related to their problems. That study was conducted in 2006, and considering the rapid increase in internet use over time, the rate of use in our research may be expected to be higher than in earlier study find- ings. Health sites online can be a source of information for patients about their health status and medications, a means of communicating with their physician, and a way to interact with other people with the same medical concerns. ${ }^{[14]}$ It must be noted, however, that misinformation on the internet can lead to serious public health problems. The quality of the information provided on health sites is critical. $^{[15]}$

When the ideas of the patients about the information they gathered from internet sources were investigated, $31 \%$ of them reported that this information was impressive, $27 \%$ of them said they found it confusing, and $76 \%$ reported that it was contradictory. When they were asked about the reliability of the information, $60.7 \%$ of them responded that it was partially reliable, $23.9 \%$ said it was reliable, and $4.3 \%$ of them replied that it was not credible. ${ }^{[6,17]}$

Studies about people researching information from the internet for medical purposes have found that the relationhip between socioeconomic status and the frequency of internet usage was statistically significant. People with a high socioeconomic status access health sites more frequently than those with a lower socioeconomic status. ${ }^{[18]}$ Discussion of health information accessed from internet sources with health professionals may result in more effective decisions about health problems. ${ }^{[19]}$

In our study, 44 I patients (39.4\%) did not utilize the internet to obtain information about their upcoming anesthetic procedure. In a study by Kurup et al.," ${ }^{[20]} 877$ patients replied to a 20 -item questionnaire about their internet usage characteristics and searching for details about an upcoming surgery. Only 36 (4\%) searched for information about their anesthesia procedure. Of those 36 patients, $14(39 \%)$ reported that the sites they used adequately answered their questions regarding anesthesia.

The majority of the participants in our study defined the internet as a source of information, but most of them reported that they did not find adequate information about anesthesia from internet sites. This rate is lower than that seen in other studies related to different branches of the medicine. ${ }^{[21-23]}$

In our study, $54.3 \%$ of the patients found the healthcare information found on the internet to be "not useful," while $64.6 \%$ said they relied on healthcare information obtained from the internet. This rate was reported as more than $70 \%$ in a study. ${ }^{[24]} \mathrm{A}$ low rate of internet use can be associated with increased age. In our research, non-internet users were older, which is consistent with the published literature. ${ }^{[24,25]}$

Some studies have concluded that there was an insignificant relationship between gender and the rate of internet use about disease, ${ }^{[24,25]}$ but in our research, we found greater use in male patients. 
The relationship between income, education, age, and internet usage is significant. Examination of our results indicated that more internet users are younger, with high levels of education, and have more disposable income compared with non-internet users.

Most of the patients in our study were familiar with the term "anesthesia" (86.9\%). In all, $67.5 \%$ of the study patients acknowledged a fear of anesthesia, and $65.1 \%$ of them wanted to see the anesthetist before the operation (Table 4). The most investigated subjects on the internet among the study group were complications of anesthesia and deaths related to anesthesia (Table 3).

Most of the patients in our study were classified as ASA I or II, and this generally good health status may also be a contributing reason for the lower proportion of internet usage to gather preoperative information.

Our patient population was small and was drawn from a single anesthesia clinic during a limited period. This may be a limitation of our study, but unlike other studies reviewed in this discussion, our patient population had varied diagnoses.

\section{Conclusion}

Younger patients with a higher educational and economic status tend to use the internet to research information about anesthesia more commonly and efficiently.But internet usage regarding anesthesia procedures is still low overall. Providing correct, understandable, and reliable information about anesthesia on internet sites will be very useful and an efficient way to improve the preoperative knowledge of patients. Further studies with a larger number of participants and focusing on specific parameters are probably needed.

\section{Ethics Committee Approval}

Approval has been obtained from the Kartal Dr. Lutfi Kırdar Training and Research Hospital Ethics Committee.

\section{Informed Consent}

A survey study. Approval was obtained from the patients.

Peer-review

Internally peer-reviewed.

Authorship Contributions

Concept: B.Ç., Y.Y.; Design: B.Ç., Y.Y., K.H.E.; Data collection \&/or processing: B.Ç.; Analysis and/or interpretation: B.Ç., Y.Y., K.H.E.; Literature search: Y.Y., K.H.E.; Writing: Y.Y., K.H.E.; Critical review: B.Ç., Y.Y., K.H.E.

Conflict of Interest

None declared.

\section{REFERENCES}

1. Diaz JA, Griffith RA, Ng JJ, Reinert SE, Friedmann PD, Moulton
AW. Patients' use of the Internet for medical information. J Gen Intern Med 2002;17:180-5. [CrossRef]

2. Andreassen HK, Bujnowska-Fedak MM, Chronaki CE, Dumitru RC, Pudule I, Santana S, et al. European citizens' use of E-health services: a study of seven countries. BMC Public Health 2007;7:53.

3. Semere W, Karamanoukian HL, Levitt M, Edwards T, Murero M, D'Ancona G, et al. A pediatric surgery study: parent usage of the Internet for medical information. J Pediatr Surg 2003;38:560-4.

4. Iverson SA, Howard KB, Penney BK. Impact of internet use on healthrelated behaviors and the patient-physician relationship: a surveybased study and review.J Am Osteopath Assoc 2008;108:699-711.

5. Lööf G, Liljeberg C, Eksborg S, Lönnqvist PA. Interactive web-based format vs conventional brochure material for information transfer to children and parents: a randomized controlled trial regarding preoperative information. Paediatr Anaesth 2017;27:657-64. [CrossRef]

6. Wieser T, Steurer MP, Steurer M, Dullenkopf A. Factors influencing the level of patients using the internet to gather information before anaesthesia: a single-centre survey of 815 patients in Switzerland : The internet for patient information before anaesthesia. BMC Anesthesiol 2017;17:39. [CrossRef]

7. Doyle DJ, Ruskin KJ, Engel TP. The Internet and medicine: past, present, and future. Yale J Biol Med 1996;69:429-37.

8. Jadad AR. Promoting partnerships: challenges for the internet age. BMJ 1999;319:761-4. [CrossRef]

9. Internet World Stats. Internet users in the World 2012. Available at: http://www.internetworldstats.com/stats.htm. Accessed Jun 2017.

10. Turkey Prime Ministry Turkish Statistical Institute News Bulletin. Household informatics technology usage investigation 2012. Available at: http://www.tuik.gov.tr. Accessed Jun 2017.

11. Nicholas D, Huntington P, Gunter B, Russell C, Withey R. The British and their use of the web for health information and advice: a survey. Aslib Proc 2003;55:261-76. [CrossRef]

12. Fox S. Older Americans and the Internet. Washington DC, USA: Pew Internet and American Life Project. 2004, Smith A. Mobile Access. Washington DC, USA: Pew Internet and American Life Project 2010.

13. Schwartz KL, Roe T, Northrup J, Meza J, Seifeldin R, Neale AV. Family medicine patients' use of the Internet for health information: a MetroNet study. J Am Board Fam Med 2006;19:39-45. [CrossRef]

14. Weaver JB 3rd, Mays D, Lindner G, Eroglu D, Fridinger F, Bernhardt JM. Profiling characteristics of internet medical information users. J Am Med Inform Assoc 2009;16:714-22. [CrossRef]

15. Wong C, Harrison C, Britt H, Henderson J. Patient use of the internet for health information. Aust Fam Physician 2014;43:875-7.

16. Sadasivam RS, Kinney RL, Lemon SC, Shimada SL, Allison JJ, Houston TK. Internet health information seeking is a team sport: analysis of the Pew Internet Survey. Int J Med Inform 2013;82:193-200.

17. Murray G, O'Rourke C, Hogan J, Fenton JE. Detecting internet search activity for mouth cancer in Ireland. Br J Oral Maxillofac Surg 2016;54:163-5. [CrossRef]

18. Broom A. Medical specialists' accounts of the impact of the Internet on the doctor/patient relationship. Health (London) 2005;9:319-38.

19. Eysenbach G. Poverty, human development, and the role of eHealth. J Med Internet Res 2007;9:e34. [CrossRef]

20. Kurup V, Considine A, Hersey D, Dai F, Senior A, Silverman DG, et al. Role of the Internet as an information resource for surgical patients: a survey of 877 patients. Br J Anaesth 2013;110:54-8. [CrossRef]

21. Helft PR, Hlubocky F, Daugherty CK. American oncologists' views of 
internet use by cancer patients: a mail survey of American Society of Clinical Oncology members. J Clin Oncol 2003;21:942-7. [CrossRef]

22. Pautler SE, Tan JK, Dugas GR, Pus N, Ferri M, Hardie WR, et al. Use of the internet for self-education by patients with prostate cancer. Urology 2001;57:230-3. [CrossRef]

23. Sahin C, Tuncer M, Yazici O, Kafkasli A, Can U, Eryildirim B, et al. The importance of Internet usage for urologic patients. Arch Ital Urol
Androl 2014;86:261-5. [CrossRef]

24. Pautler SE, Tan JK, Dugas GR, Pus N, Ferri M, Hardie WR, et al. Use of the internet for self-education by patients with prostate cancer. Urology 2001;57:230-3. [CrossRef]

25. Stark-Wroblewski K, Edelbaum JK, Bello TO. Perceptions of aging among rural, midwestern senior citizens: signs of women's resiliency.J Women Aging 2008;20:361-73. [CrossRef]

\section{Bir Anesteziyoloji Kliniğinde Hastaların İnternet Kullanım Karakteristiklerinin Ameliyat Öncesi Değerlendirilmesi: 1000 Hastalık Bir Anket Çalışması}

Amaç: Bu çalışma 3. basamak bir eğitim ve araştırma hastanesinde elektif cerrahi işlem uygulanacak hastaların anesteziyoloji ile ilgili bilgi edinmek için internet kullanımları ile ilgili verileri toplamayı amaçlamaktadır.

Gereç ve Yöntem: Yerel etik kurul onayından sonra anesteziyoloji ve reanimasyon polikliniğine elektif cerrahi öncesi ameliyat öncesi değerlendirme için başvuran 1000 hastadan onamları alındıktan sonra anket uygulandı. Tamamlanmış tüm anket cevaplarına NCSS (Number Cruncher Statistical System) ile istatistiksel analiz uygulandı. Kategorik verilerin değerlendirilmesinde ki-kare testi, sürekli verilerin analizinde ise t-testi kullanıldı. $\mathrm{P}<0.05$ istatistiksel olarak anlamlı kabul edildi.

Bulgular: Bin hastanın 659'u (\%65.9) rutin internet kullandıklarını bildirmişlerdir. Bunların, 559'u (\%55.9) İnternetten gerekli sağık bilgilerini elde edebilmişlerdir. Altı yüz otuz altısı (\%63.6) 'anestezi', 387’si (\%38.7) 'genel anestezi', 245’i (\%24.5) 'spinal anestezi', I30'u (\%।3) 'epidural anestezi', 589'u (\%58.9) 'anestezi ile ilişkili komplikasyonlar', 498'u (\%49.8) 'anestezi ile ilişkili ölümler' ve 33 I’i (\%33.I) 'diğer tıbbi konular'। araştırdıklarını bildirmişlerdir. Geriye kalan 364 hasta (\%36.4) anestezi ilişkili herhangi bir konuda İnternette araştırma yapmadıklarını bildirmişlerdir.

Sonuç: Hasta ve hasta yakınlarının doğru, anlaşılır ve güvenli bilgiler elde edebilmeleri için sağlık merkezlerinin İnternet sitelerinde güncel ve kanıta dayalı bilgiler yer almalıdır. Hastaların bilinmezlik nedeniyle karşı karşıya geldikleri anksiyete ile baş edebilmeleri için anesteziyolojik işlemler ve olası komplikasyonlar hakkında preoperatif bilgilendirilmeleri yardımcı olacaktır.

Anahtar Sözcükler: Ameliyat öncesi; anestezi; hasta; internet. 